\title{
Abnormal Finding
}

National Cancer Institute

\section{Source}

National Cancer Institute. Abnormal Finding. NCI Thesaurus. Code C82547.

A decision that an observation or result is outside the parameters considered normal. 